\title{
Molecular and biochemical investigations of key antioxidant/oxidant molecules in Saudi patients with recurrent miscarriage
}

\author{
YAZEED A. AL-SHEIKH ${ }^{1}$, HAZEM K. GHNEIM ${ }^{1}$, ADEL F. ALHARBI ${ }^{1}$, MASHAEL M. ALSHEBLY ${ }^{2}$, \\ FEDA S. ALJASER ${ }^{1}$ and MOURAD A.M. ABOUL-SOUD ${ }^{1}$ \\ ${ }^{1}$ Chair of Medical and Molecular Genetics Research, Department of Clinical Laboratory Sciences, \\ College of Applied Medical Sciences, King Saud University, Riyadh $11433 ;{ }^{2}$ Department of Obstetrics and Gynaecology, \\ College of Medicine, King Saud University, Riyadh 11472, Kingdom of Saudi Arabia
}

Received May 13, 2019; Accepted August 21, 2019

DOI: $10.3892 /$ etm.2019.8082

\begin{abstract}
The present study was undertaken to: i) Determine the levels of oxidative stress (OS) markers, malondialdehyde (MDA), superoxide anions (SOA) and hydrogen peroxide $\left(\mathrm{H}_{2} \mathrm{O}_{2}\right)$, in both plasma and placental tissues of recurrent miscarriage $(\mathrm{RM})$ patients in comparison with those of healthy pregnant (HP) and non-pregnant (NP) women; ii) determine the levels of enzymatic antioxidants [glutathione peroxidase (GPx), glutathione reductase (GSR), superoxide dismutase (SOD) and catalase (CAT)], and non-enzymatic antioxidant micronutrients [selenium $(\mathrm{Se})$, zinc $(\mathrm{Zn})$, copper $(\mathrm{Cu})$ and manganese $(\mathrm{Mn})]$ in both plasma and placental tissues of RM patients, in comparison with those of HP and NP women; iii) profile differential expression levels of selected antioxidant and apoptosis-related genes in the placental tissues of RM cases, in relation to those of HP women of matched gestational age, using reverse transcription-quantitative polymerase chain reaction (RT-qPCR). The results revealed highly significant increases of all investigated OS markers in plasma and placental tissues of RM patients compared with those of HP women. Moderate, but significant, increases of OS markers were observed in the plasma of HP patients in relation to those of NP women. The activities of antioxidant enzymes exhibited statistically significant decreases in both plasma and placental tissues of RM patients compared with those of HP women. The significantly reduced level of antioxidant enzymes was also evident in the plasma of HP women as compared with those of NP women. Results of RT-qPCR assays clearly indicated
\end{abstract}

Correspondence to: Professor Mourad A.M. Aboul-Soud, Chair of Medical and Molecular Genetics Research, Department of Clinical Laboratory Sciences, College of Applied Medical Sciences, King Saud University, PO Box 10219, Riyadh 11433, Kingdom of Saudi Arabia

E-mail: maboulsoud@ksu.edu.sa

Key words: idiopathic recurrent miscarriage, oxidative stress, gene expression, antioxidant enzymes, placental tissue, plasma that the expression level of apoptosis-related genes [tumor necrosis factor-related apoptosis-inducing ligand (TRAIL) and S100A8], and pro-inflammatory cytokine genes [tumor necrosis factor- $\alpha(T N F-\alpha)$, interleukin $(I L)-6$ and $I L-8]$ were significantly upregulated in placental tissue of RM cases in relation to those of HP subjects. By contrast, mRNA transcriptional levels of key antioxidant genes (GPx, SOD, GSR and CAT) were found to be significantly reduced in placental tissue of RM patients in comparison to those of HP women. In conclusion, our data highlight a plausible cause-effect association between the observed increase in placental OS level and depletion of the activity of antioxidant enzymes. This suggests that OS is a contributing factor in the pathogenesis of idiopathic RM.

\section{Introduction}

Recurrent miscarriage (RM) is a common gestational complication that affects $2-5 \%$ of couples trying to conceive $(1,2)$, and previous successful live birth does not preclude its development (3). RM is considered to be a multifactorial disorder that may result from either acquired or inherited factors (4). Several studies have been conducted to examine and identify the molecular mechanism underlying the pathophysiology of RM and yet $50-60 \%$ of the cases are of unknown cause $(4,5)$.

Although oxygen is essential for normal cell function, it poses a risk by producing some toxic derivatives through extensive metabolism (5). Several studies have suggested that the oxidative stress (OS) generated during angiogenesis and placental development might be the cause of idiopathic $\mathrm{RM}(2,5-10)$. OS is known to result when there is an increased production of reactive oxygen species (ROS) that cannot be balanced by the produced antioxidants. However, ROS are naturally produced during oxygen reduction and within limited levels can act as essential regulators for several cell functions, in addition to playing an important role in several reproductive processes (11). Increased ROS levels are common during placental development and are normally balanced by higher levels of antioxidants (9).

Superoxide anions (SOA), hydrogen peroxide $\left(\mathrm{H}_{2} \mathrm{O}_{2}\right)$, and hydroxyl radicals $(\cdot \mathrm{OH})$ are the most commonly generated 
ROS in an electron-rich environment, which mainly occurs within the mitochondrial inner membrane and the respiratory chain $(6,12)$. The conversion of oxygen to SOA mainly results after the leakage of $1-3 \%$ of electrons through respiratory chain complex I and III $(5,12,13)$. Aerobic cells balance SOA by its dismutation into $\mathrm{H}_{2} \mathrm{O}_{2}$ through antioxidant superoxide dismutase (SOD) (6). Other antioxidants that can convert SOA into $\mathrm{H}_{2} \mathrm{O}_{2}$ include cytosolic copper $(\mathrm{Cu})$ and zinc $(\mathrm{Zn})$ dismutase and mitochondrial manganese $(\mathrm{Mn})$ SOD (7). Glutathione peroxidase (GPx) and catalase (CAT) antioxidant enzymes can then transform $\mathrm{H}_{2} \mathrm{O}_{2}$ into water. In addition, GPx can also reduce lipid hydroperoxides into water by transferring the energy of those reactive peroxides to reduced glutathione (GSH), and thus, resulting in oxidised glutathione (GSSG). This can then be reduced back to GSH by the enzyme glutathione reductase (GSR) via donated electron by NADPH $(7,14)$. However, excessive unbalanced ROS can induce cytotoxicity by alteration in gene expression including genes related to apoptosis (7).

Although, several studies have suggested that OS may be a strong factor causing RM, there is a lack of consensus in the literature. Therefore, the present study was conducted to gain further knowledge regarding the impact of OS and the efficiency of antioxidants in RM cases by examining free radicals and OS markers in addition to measurements of antioxidant levels in placental tissue and plasma from RM patients with reference to healthy pregnant (HP) women. Moreover, these assays are paralleled by profiling the differential expression level of selected antioxidant, pro-inflammatory and apoptosis-related genes in the placental tissues of RM cases in relation to HP women.

\section{Patients and methods}

All materials and solutions were purchased from Sigma-Aldrich (Merck KGaA), unless otherwise specified.

Samples, collection and preparation. The study included consenting patients who attended the Department of Obstetrics and Gynaecology at the King Khalid University Hospital (Riyadh, Kingdom of Saudi Arabia) from September 2014 to January 2015, who signed the consent forms provided. Ethics approval was obtained from the Ethics Review Committee of the College of Applied Medical Sciences of King Saud University (CAMS 27-34/35) and the study was conducted according to the Declaration of Helsinki.

Placental tissue and blood plasma of idiopathic RM women of at least 3 consecutive miscarriages $(n=28), 35.8 \pm 5.3$ years of age, and of HP women $(n=28)$, with no miscarriage history, $29.3 \pm 2.7$ years of age, were examined. Blood plasma samples were also collected from non-pregnant women (NP) $(n=28)$, $28.6 \pm 4.91$ years of age. Patients with RM were excluded from the study if there were risk factors, such as abnormal menstrual cycle ( $<21$ and $>35$ days), genital infections, antiphospholipid syndrome (positive anticardiolipin and/or b2 glycoprotein 1 antibodies), and uterus anomalies (observed by ultrasound examination or hysterosonography). No anticoagulant or immunological treatment was applied during the pregnancy. Gestational age of RM patients at the time of miscarriage was $12.6 \pm 2.8$ weeks, with an average of $3.5 \pm 0.8$ miscarriages.
Maternal blood and placental tissue samples were collected at the time of delivery from HP women or at the time of miscarriage from RM patients. Full depth placental tissue was collected, in which the Decidua basalis and the chorionic plate was trimmed off, leaving trophoblastic tissue. Tissue was then washed in $0.1 \mathrm{M}$ phosphate-buffered saline (PBS) and dissected into $1.5 \mathrm{~g}$ pieces and placed into two Corning ${ }^{\circledR}$ cryogenic vials (Corning, Inc.). One contained RNAlater ${ }^{\circledR}$ (Thermo Fisher Scientific, Inc.) $\left(4^{\circ} \mathrm{C}\right)$ for immediate RNA stabilization and protection, and thus, reliable gene expression profiling, while the other contained PBS for biochemical assays. All collected tubes were kept at $4{ }^{\circ} \mathrm{C}$ for $24 \mathrm{~h}$. Subsequently, cryovials were immediately snap-frozen in liquid nitrogen prior to storage at $-80^{\circ} \mathrm{C}$ until further use. Venous blood samples $(6 \mathrm{ml})$ were collected from all participants into cold BD Vacutainer ${ }^{\mathrm{TM}}$ Plastic Blood Collection Tubes (BD Biosciences) with $\mathrm{K}_{2}$ EDTA for the measurement of biochemical OS markers ( $\mathrm{SOA}, \mathrm{H}_{2} \mathrm{O}_{2}$ and lipid peroxides), activities of antioxidant enzymes (SOD, GPx, GSR and CAT), in addition to the non-enzymatic antioxidants GSH, Zn, selenium (Se), and $\mathrm{Cu}$. All centrifugation steps were conducted at room temperature. Plasma was obtained by centrifugation at $3,000 \mathrm{x} \mathrm{g}$ for $20 \mathrm{~min}$ and then transferred into the Eppendorf tubes within $1 \mathrm{~h}$ and stored at $-80^{\circ} \mathrm{C}$. For GSH and GSSG analysis, whole blood aliquot samples $(30 \mu \mathrm{l})$ were centrifuged and $33.3 \mu \mathrm{l}$ of 5 -sulphosalicylic acid $(1 \mathrm{~g} / \mathrm{ml})$ were added for protein precipitation and cellular disruption to release GSH. Samples were then diluted with $936.7 \mu$ l sodium phosphate buffer ( $\mathrm{pH} 7.5$ ) and then centrifuged for $5 \mathrm{~min}$ at $12,000 \mathrm{x} \mathrm{g}$, and the supernatant was kept at $-80^{\circ} \mathrm{C}$ until the time of analysis.

\section{Measurement of OS markers}

$\mathrm{H}_{2} \mathrm{O}_{2}$. Levels of $\mathrm{H}_{2} \mathrm{O}_{2}$ were measured as described previously (7). Briefly, reaction mix (horseradish peroxidase dissolved in Kreb's Ringer buffer $10 \mu \mathrm{g} / \mathrm{ml}, 100 \mu \mathrm{l}$; sodium phosphate reaction buffer $50 \mathrm{mM}$; $\mathrm{pH} 7.4$ ) was added to $50 \mu \mathrm{l}$ diluted samples and standards and incubation followed for $30 \mathrm{~min}$ at room temperature. A total of $50 \mu \mathrm{l}$ of $10 \mathrm{mM}$ Amplex Red Reagent (ARR; 10-acetyl-3,7-dihydrophenoxazine; Thermo Fisher Scientific, Inc.) was added to commence reaction, and fluorescence was measured at $590 \mathrm{~nm}$. ARR reacts with $\mathrm{H}_{2} \mathrm{O}_{2}$ in the presence of peroxide resulting in red fluorescent oxidation resorufin products.

SOA. Samples $(0.1 \mathrm{ml})$ were incubated for $5 \mathrm{~min}$ at $37^{\circ} \mathrm{C}$ with $1 \mathrm{ml}$ of PBS ( $2 \mathrm{~g}$ glucose, $2 \mathrm{~g}$ of fatty acid-free bovine serum albumin/l) with and without $30 \mu \mathrm{g}$ SOD following previous publication $(6,15)$, and were mixed with $0.1 \mathrm{ml}$ reaction solution of ferricytochrome-c $(1.2 \mathrm{mM})$. Tube containing only buffer and ferricytochrome-c was used as blank control. A spectrophotometer, equipped with a thermostated cuvet, was used for measuring absorbance at $550 \mathrm{~nm}$. Results were converted to $\mathrm{nM}$ of reduced ferricytochrome-c by using an absorptivity value of $1.96 \times 10^{4} 1 \cdot \mathrm{mol}^{-1}$. SOA levels were determined by calculating the difference between the samples without SOD and the samples with added SOD.

Lipid peroxidation ( $L P O)$. The level of the end product of LPO was determined, malondialdehyde (MDA), using thiobarbituric acid (TBA) which reacts with MDA producing a fluorescence product that can be measured by spectrophotometry $(7,16,17)$. Briefly, plasma $(150 \mu \mathrm{l})$ or placental tissue 
supernatant $(1 \mathrm{ml})$ was mixed with $1 \mathrm{ml}$ trichloroacetic acid (17.5\%) and $1 \mathrm{ml}$ TBA (0.6\%), followed by incubation in hot water bath $\left(100^{\circ} \mathrm{C}\right)$ for $15 \mathrm{~min}$, and then left to cool. After that, $1 \mathrm{ml}$ trichloroacetic acid (70\%) was added to the mixture, incubated for $20 \mathrm{~min}$ at room temperature, and then centrifuged at 2,000 x g for $15 \mathrm{~min}$. The supernatant was decanted and the absorbance was measured at $535 \mathrm{~nm}$. Applying $1.56 \times 10^{5} \mathrm{M}^{-1} \cdot \mathrm{cm}^{-1}$ as an extinction coefficient, MDA levels were calculated.

Enzymatic assays for enzymatic antioxidant measurements. Frozen tissue was thawed in ice, homogenized in $0.1 \mathrm{M}$ potassium chloride buffer, and centrifuged at $10,000 \times \mathrm{g}, 4^{\circ} \mathrm{C}$ for $10 \mathrm{~min}$. Supernatants were used for different assays.

Measurement of SOD activity. Serum samples $(250 \mu \mathrm{l})$

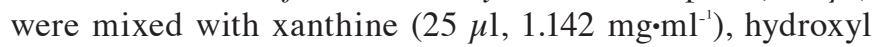
ammonium chloride $(25 \mu \mathrm{l})$, water $(125 \mu \mathrm{l})$, and xanthine oxidase $\left(75 \mu \mathrm{l}, 0.1 \mathrm{U} \cdot \mathrm{ml}^{-1}\right)$. The mixture was incubated at $25^{\circ} \mathrm{C}$ for $20 \mathrm{~min}$, and sulphonilic acid $\left(0.5 \mathrm{ml}, 3.3 \mathrm{mg} \cdot \mathrm{ml}^{-1}\right)$ and $\alpha$-naphthylamine $\left(0.5 \mathrm{ml}, 1 \mathrm{ng} \cdot \mathrm{ml}^{-1}\right)$ were added, and further incubated at room temperature for $20 \mathrm{~min}$. Absorbance was measured at $530 \mathrm{~nm}$.

Measurement of CAT activity. CAT activity was measured as previously described (18), using $\mathrm{H}_{2} \mathrm{O}_{2}$ as the substrate. The decomposition of $\mathrm{H}_{2} \mathrm{O}_{2}$ was observed at $240 \mathrm{~nm}$ by measuring the decrease in absorbance. The activity was expressed as $\mu \mathrm{M} / \mathrm{min} / \mathrm{mg}$ protein using a coefficient of $0.0436 \mathrm{mM}^{-1} \cdot \mathrm{mg}^{-1}$.

Measurement of GPx activity. GPx activity was measured as described previously (19). Briefly, assay solution $(800 \mu \mathrm{l})$ of $50 \mathrm{mM}$ Tris-HCl buffer (pH 7.6), 1 mM EDTA, 1 IU GSR, $0.25 \mathrm{mM}$ GSH and $0.2 \mathrm{mM}$ NADPH were added to diluted plasma $(1: 10 ; 50 \mu \mathrm{l})$ or placental tissue supernatant $(50 \mu \mathrm{l})$. After $5 \mathrm{~min}, 100 \mu \mathrm{l}$ of $\mathrm{H}_{2} \mathrm{O}_{2}(15 \mathrm{mM})$ were added to the sample mix and the absorbance change was examined at $340 \mathrm{~nm}$ for $30 \mathrm{~min}$. GPx activity was determined by calculating the enzyme catalysing the oxidation of $1 \mu \mathrm{M}$ or $1 \mathrm{nM}$ GSH per minute.

Measurement of GSR activity. GSR activity was determined following a previously described protocol (7). Briefly, $100 \mu \mathrm{l}$ serum samples were added to $2 \mathrm{ml}$ reaction mix (100 mM potassium phosphate buffer $\mathrm{pH} 7.4,50 \mu \mathrm{l}$ of $80 \mathrm{mM}$ EDTA, $100 \mu 12 \mathrm{mM}$ NADPH, and $100 \mu \mathrm{l}$ of $0.3 \mathrm{mM}$ flavine adenine dinucleotide) and incubated for 2 min followed by addition of $100 \mu \mathrm{l} \mathrm{GSSG}(7.5 \mathrm{mM})$. Using a spectrophotometer, reaction was examined at $340 \mathrm{~nm}$ for $2 \mathrm{~min}$. One unit of GSR is equal to the amount of enzyme to reduce $1 \mu \mathrm{M}$ of $\mathrm{NADPH} / \mathrm{min}$ at $25^{\circ} \mathrm{C}$.

\section{Non-enzymatic assays}

Measurement of GSH and GSSG. Following a previous described protocol $(20,21)$, glutathione reductase-DTNB (5,5-dithiobis-2-nitrobenzoic acid) was used to determine the GSH levels. Twenty-five microliters of samples and standards (ranging from 20 to $80 \mu \mathrm{M}$ ) were incubated separately for $3 \mathrm{~min}$ at $37^{\circ} \mathrm{C}$ with the reaction mix $(150 \mu \mathrm{l}$ of $100 \mathrm{mM}$ sodium phosphate buffer $\mathrm{pH} 7.4,50 \mu \mathrm{l}$ of $8 \mathrm{mM}$ EDTA, $50 \mu \mathrm{l}$ DNTB solution, and $100 \mu \mathrm{l}$ of $2 \mathrm{mM}$ NADPH). Then, $25 \mu \mathrm{l}$ glutathione reductase were added and absorbance was measured at $410 \mathrm{~nm}$. GSSG was measured similarly, but the reaction mix also contained triethanolamine, to prevent $\mathrm{pH}$ increase and oxidation, and 2-vinyl pyridine for GSH derivatization.
GSSG standards ranged from 0 to $10 \mu \mathrm{M}$ and were examined simultaneously.

Measurement of $\mathrm{Se}, \mathrm{Zn}, \mathrm{Cu}$ and $\mathrm{Mn}$ antioxidants. Both plasma and placental tissue were freeze dried at $-45^{\circ} \mathrm{C}$ and ground into powder. Ground plasma (100 mg) and $20 \mathrm{mg}$ of ground placental tissue were used, in which samples were digested with ultra-pure nitric acid $(0.5 \mathrm{ml}, 68 \%)$ and $\mathrm{H}_{2} \mathrm{O}_{2}(0.2 \mathrm{ml}$, $35 \%)$. The product was diluted using ultra-pure water and then measured for $\mathrm{Se}, \mathrm{Cu}, \mathrm{Zn}$ and $\mathrm{Mn}$ using inductively coupled plasma mass spectrometry (ICP-MS) (HP 4500; Yokokawa Electric Co.), as described previously (22).

Gene expression profiling. Placental tissue samples previously stored in RNAlater ${ }^{\circledR}$ at $-80^{\circ} \mathrm{C}$ were allowed to thaw on ice, and were subsequently used for total RNA extraction and relative gene expression quantification using reverse transcription-quantitative polymerase chain reaction (RT-qPCR). Approximately $100 \mathrm{mg}$ of placental tissues were homogenized in $1 \mathrm{ml} \mathrm{TRIzol}{ }^{\circledR}$ reagent (Invitrogen; Thermo Fisher Scientific, Inc.) by the use of TissueLyser LT (Qiagen, Inc.), and total RNA was subsequently extracted by standard procedure. Genomic DNA was then eliminated and cDNA was synthesized from total RNA $(1 \mu \mathrm{g})$ in a final reaction volume of $20 \mu \mathrm{l}$ using the QuantiTect Reverse Transcription kit (QuantiTect ${ }^{\circledR}$; Qiagen, Inc.), according to the manufacturer's instructions. The RT reaction was carried out on Veriti ${ }^{\circledR}$ 96-Well Thermal Cycler (Applied Biosystems) at $42^{\circ} \mathrm{C}$ for $45 \mathrm{~min}$ and then inactivated at $95^{\circ} \mathrm{C}$ for $15 \mathrm{~min}$. The resultant diluted cDNA (1:10, $5 \mu \mathrm{l}$ ) was then used to perform RT-qPCR using the QuantiTect SYBR-Green PCR kit (Qiagen, Inc.). A total of $100 \mathrm{nM}$ of the following gene primers were used: CAT (Hs_CAT_1_SG QuantiTect Primer Assay, QT00079674); GPx (Hs_GPx_1_SG QuantiTect Primer Assay, QT00203392); GSR (Hs-GSR_1_SG QuantiTect Primer Assay, QT00038325); SOD (Hs_SOS_1_ SG QuantiTect Primer Assay, QT01664327); tumor necrosis factor- $\alpha(T N F-\alpha)($ Hs_TNF_3_SG QuantiTect Primer Assay, QT01079561); interleukin (IL)-6 (Hs_IL6_1_SG QuantiTect Primer Assay, QT00083720); IL-8 (Hs_IL8_1_SG QuantiTect Primer Assay, QT00000322); and 18S (Hs_RRN18S_1_SG QuantiTect Primer Assay, QT00199367), in a final reaction volume of $25 \mu 1$, containing the cDNA sample $(5 \mu 1)$, SYBR-Green PCR Master mix (12.5 $\mu \mathrm{l})$, QuantiTect ${ }^{\circledR}$ Primer Assay (10X, $2.5 \mu \mathrm{l}$ ), and RNase-free water (2.5 $\mu \mathrm{l})$. A two-step cycling reaction was conducted; following an initial polymerase activation at $95^{\circ} \mathrm{C}$ for $10 \mathrm{~min}$, samples were subjected to 40 cycles of i) denaturation at $95^{\circ} \mathrm{C}$ for $15 \mathrm{sec}$, followed by ii) annealing and elongation at $60^{\circ} \mathrm{C}$ for $1 \mathrm{~min}$. TaqMan ${ }^{\circledR}$ gene expression assays (Applied Biosystems) were performed with the following gene primers: tumor necrosis factor-related apoptosis-inducing ligand (TRAIL) (Hs00921974_ml TaqMan ${ }^{\circledR}$ Gene Expression); calcium binding protein A8 (S100A8) (Ha00374263_ml TaqMan ${ }^{\circledR}$ Gene Expression); and TaqMan endogenous housekeeping gene, hypoxanthine-guanine phosphoribosyltransferase (HPRT1). The amplification program and PCR amplicon specificity were performed and assessed as documented by us previously (6). A three-step cycling reaction was carried out; following an initial polymerase activation at $95^{\circ} \mathrm{C}$ for $10 \mathrm{~min}$, samples were subjected to 40 cycles of i) denaturation at $95^{\circ} \mathrm{C}$ for $15 \mathrm{sec}$, followed by ii) annealing at $55^{\circ} \mathrm{C}$ 
Table I. Levels of $\mathrm{H}_{2} \mathrm{O}_{2}$, SOA, and MDA, which is used as an index of LPO, in plasma and placental tissue of NP, HP and RM women.

Subjects

\begin{tabular}{lccc}
\cline { 2 - 4 } Assayed parameters & NP women $(\mathrm{n}=28)$ & HP women $(\mathrm{n}=28)$ & RM women $(\mathrm{n}=28)$ \\
\hline Plasma $\mathrm{H}_{2} \mathrm{O}_{2}(\mathrm{nmol} / \mathrm{ml})$ & $7.04 \pm 1.12$ & $8.11 \pm 1.14^{\mathrm{a}}$ & $10.2 \pm 1.47^{\mathrm{b}, \mathrm{c}}$ \\
Placental tissue $\mathrm{H}_{2} \mathrm{O}_{2}(\mathrm{nmol} / \mathrm{min} / \mathrm{mg})$ & - & $2.41 \pm 0.35$ & $3.38 \pm 0.46^{\mathrm{d}}$ \\
Plasma $\mathrm{SOA}(\mathrm{nmol} / \mathrm{ml})$ & $30.1 \pm 4.50$ & $35.3 \pm 5.45^{\mathrm{a}}$ & $45.2 \pm 6.10^{\mathrm{b}, \mathrm{c}}$ \\
Placental tissue $\mathrm{SOA}(\mu \mathrm{mol} / \mathrm{min} / \mathrm{mg})$ & - & $4.67 \pm 0.62$ & $5.93 \pm 0.78^{\mathrm{d}}$ \\
Plasma $\mathrm{MDA}(\mathrm{nmol} / \mathrm{ml})$ & $5.03 \pm 0.70$ & $5.73 \pm 0.76^{\mathrm{a}}$ & $7.87 \pm 0.96^{\mathrm{b}, \mathrm{c}}$ \\
Placental tissue $\mathrm{MDA}(\mathrm{nmol} / \mathrm{g}$ wet weight $)$ & - & $258 \pm 35.7$ & $334 \pm 45.8^{\mathrm{d}}$
\end{tabular}

${ }^{\mathrm{a}} \mathrm{P}<0.05$, compared with plasma of NP women; ${ }^{\mathrm{b}} \mathrm{P}<0.0001$, compared with plasma of NP women; ${ }^{\mathrm{c}} \mathrm{P}<0.001$, compared with plasma of HP women; ${ }^{d} \mathrm{P}<0.0001$, compared with placental tissue of HP women. $\mathrm{H}_{2} \mathrm{O}_{2}$, hydrogen peroxide; SOA, superoxide anions; MDA, malondialdehyde; LPO, lipid peroxidation; NP, non-pregnant; HP, healthy pregnant; RM, recurrent miscarriage.

Table II. GPx, GSR, CAT and SOD enzymatic activities in plasma and placental tissue of NP, HP and RM women.

\begin{tabular}{lccc}
\hline & & \multicolumn{2}{c}{ Subjects } \\
\cline { 2 - 4 } Assayed parameters & NP women $(\mathrm{n}=28)$ & HP women $(\mathrm{n}=28)$ & RM women $(\mathrm{n}=28)$ \\
\hline Plasma GPx $(\mathrm{nmol} / \mathrm{min} / \mathrm{ml})$ & $1.19 \pm 0.17$ & $1.06 \pm 0.13^{\mathrm{a}}$ & $0.86 \pm 0.10^{\mathrm{b}, \mathrm{c}}$ \\
Placental tissue GPx $(\mu \mathrm{mol} / \mathrm{min} / \mathrm{mg}$ protein) & - & $0.36 \pm 0.04$ & $0.28 \pm 0.04^{\mathrm{d}}$ \\
Plasma GSR $(\mathrm{nmol} / \mathrm{min} / \mathrm{ml})$ & $1.86 \pm 0.26$ & $1.60 \pm 0.23^{\mathrm{a}}$ & $1.29 \pm 0.17^{\mathrm{b}, \mathrm{c}}$ \\
Placental tissue GSR $(\mu \mathrm{mol} / \mathrm{min} / \mathrm{mg}$ protein) & - & $0.61 \pm 0.08$ & $0.48 \pm 0.06^{\mathrm{d}}$ \\
Plasma CAT $(\mathrm{nmol} / \mathrm{min} / \mathrm{ml})$ & $3.10 \pm 0.36$ & $2.78 \pm 0.38^{\mathrm{a}}$ & $2.25 \pm 0.30^{\mathrm{b}, \mathrm{c}}$ \\
Placental tissue CAT $(\mu \mathrm{mol} / \mathrm{min} / \mathrm{mg}$ protein) & - & $0.91 \pm 0.12$ & $0.70 \pm 0.10^{\mathrm{d}}$ \\
Plasma SOD $(\mathrm{nmol} / \mathrm{min} / \mathrm{ml})$ & $2.08 \pm 0.27$ & $1.83 \pm 0.23^{\mathrm{a}}$ & $1.48 \pm 0.20^{\mathrm{b}, \mathrm{c}}$ \\
Placental tissue SOD $(\mu \mathrm{mol} / \mathrm{min} / \mathrm{mg}$ protein) & - & $1.88 \pm 0.20$ & $1.52 \pm 0.19^{\mathrm{d}}$ \\
\hline
\end{tabular}

${ }^{\mathrm{a}} \mathrm{P}<0.05$, compared with plasma of NP women; ${ }^{\mathrm{b}} \mathrm{P}<0.0001$, compared with plasma of NP women; ${ }^{\mathrm{c}} \mathrm{P}<0.001$, compared with plasma of HP women; ${ }^{\mathrm{d}} \mathrm{P}<0.0001$, compared with placental tissue of HP women. GPx, glutathione peroxidase; GSR, glutathione reductase; CAT, catalase; SOD, superoxide dismutase; NP, non-pregnant; HP, healthy pregnant; RM, recurrent miscarriage.

for $30 \mathrm{sec}$, and iii) elongation at $72^{\circ} \mathrm{C}$ for $30 \mathrm{sec}$. Each tissue sample was represented by two biological replicas and three technical replicas, with the inclusion of a no-template control. Raw data were analyzed using the Rotor-Gene Q software version 2.3 (Qiagen, Inc.) to calculate the threshold cycle $(\mathrm{Cq})$ using the second derivative maximum method. The relative gene expression level (fold-change) was determined after normalization to the expression levels of $18 S$ and HPRT1 as a housekeeping gene for SYBR-Green and TaqMan ${ }^{\circledR}$ assays, respectively, with the $2^{-\Delta \Delta \mathrm{Cq}}$ method as previously described (6). The relative gene expression data were subjected to Student's t-test in order to identify significant differences between RM samples compared with uncomplicated HP controls. Expression levels in terms of fold change were considered statistically significant at $\mathrm{P}<0.05$.

Statistical analysis. Statistical analysis was performed using the computer-based package of Minitab software (v.13.1, 2001; Minitab Ltd.). Sample analysis was run in duplicate for all investigated parameters and results are presented as means \pm SD. Values of the activities and concentrations of individual parameters were compared between different groups of the study subjects using one-way analysis of variance (ANOVA) followed by the post-hoc Tukey-HSD test for multiple comparisons. $\mathrm{P}<0.05$ was considered to indicate a statistically significant difference.

\section{Results}

Levels of OS markers in plasma and placenta. Plasma $\mathrm{H}_{2} \mathrm{O}_{2}$ levels were significantly higher $(10.2 \pm 1.47 \mathrm{nmol} / \mathrm{ml})$ in $\mathrm{RM}$ patients in relation to both $\mathrm{HP}(8.11 \pm 1.14 \mathrm{nmol} / \mathrm{ml} ; \mathrm{P}<0.001)$ and NP $(7.04 \pm 1.12 \mathrm{nmol} / \mathrm{ml} ; \mathrm{P}<0.0001)$ subjects. HP subjects, however, showed moderately increased $(\mathrm{P}<0.05)$ plasma $\mathrm{H}_{2} \mathrm{O}_{2}$ levels compared with NP samples (Table I). Placental tissue $\mathrm{H}_{2} \mathrm{O}_{2}$ generation rates showed highly significantly elevated levels in RM patients compared with HP women $(3.38 \pm 0.46$ vs. $2.41 \pm 0.35 \mathrm{nmol} / \mathrm{min} / \mathrm{mg}$ protein, respectively, $\mathrm{P}<0.0001$; Table I). Similar increases of SOA (Table I) and MDA (Table I) were observed in both plasma and placental tissue of RM patients compared with both HP $(\mathrm{P}<0.001$ 
Table III. GSH, GSSG and GSH/GSSG ratio in plasma and placental tissue of NP, HP and RM women.

\begin{tabular}{lccc}
\hline & & \multicolumn{2}{c}{ Subjects } \\
\cline { 2 - 4 } Assayed parameters & NP women $(\mathrm{n}=28)$ & HP women $(\mathrm{n}=28)$ & RM women $(\mathrm{n}=28)$ \\
\hline Plasma GSH $(\mu \mathrm{mol} / \mathrm{l})$ & $2.86 \pm 0.30$ & $2.51 \pm 0.36^{\mathrm{a}}$ & $1.97 \pm 0.29^{\mathrm{b}, \mathrm{c}}$ \\
Placental tissue GSH $(\mathrm{nmol} / \mathrm{mg}$ tissue) & - & $6.86 \pm 0.95$ & $5.40 \pm 0.77^{\mathrm{d}}$ \\
Plasma GSSG $(\mu \mathrm{mol} / \mathrm{l})$ & $0.049 \pm 0.007$ & $0.056 \pm 0.008^{\mathrm{a}}$ & $0.071 \pm 0.010^{\mathrm{b}, \mathrm{c}}$ \\
Placental tissue GSSG (nmol/mg tissue) & - & $0.14 \pm 0.018$ & $0.18 \pm 0.025^{\mathrm{d}}$ \\
Plasma GSH/GSSG & $55.6 \pm 6.88$ & $48.5 \pm 6.61^{\mathrm{a}}$ & $28.8 \pm 3.88^{\mathrm{b}, \mathrm{c}}$ \\
Placental tissue GSH/GSSG & - & $49.6 \pm 6.75$ & $31.0 \pm 4.19^{\mathrm{d}}$ \\
\hline
\end{tabular}

${ }^{a} \mathrm{P}<0.05$, compared with plasma of NP women; ${ }^{\mathrm{b}} \mathrm{P}<0.0001$, compared with plasma of NP women; ${ }^{\mathrm{c}} \mathrm{P}<0.001$, compared with plasma of HP women; ${ }^{\mathrm{d}} \mathrm{P}<0.0001$, compared with placental tissue of HP women. GSH, reduced glutathione; GSSG, oxidised glutathione; NP, non-pregnant; $\mathrm{HP}$, healthy pregnant; RM, recurrent miscarriage.

Table IV. Se, Cu, Zn and Mn levels in plasma and placental tissue of NP, HP and RM women.

\begin{tabular}{lccc}
\hline & & Subjects & \\
\cline { 2 - 4 } Assayed parameters & NP women $(\mathrm{n}=28)$ & HP women $(\mathrm{n}=28)$ & RM women $(\mathrm{n}=28)$ \\
\hline Plasma Se $(\mu \mathrm{mol} / \mathrm{l})$ & $1.09 \pm 0.14$ & $0.95 \pm 0.13^{\mathrm{a}}$ & $0.78 \pm 0.09^{\mathrm{b}, \mathrm{c}}$ \\
Placental tissue Se $(\mathrm{nmol} / \mathrm{g})$ & - & $16.8 \pm 2.26$ & $12.0 \pm 1.73^{\mathrm{d}}$ \\
Plasma Cu $(\mu \mathrm{mol} / \mathrm{l})$ & $28.3 \pm 3.81$ & $24.5 \pm 3.41^{\mathrm{a}}$ & $19.6 \pm 2.75^{\mathrm{b}, \mathrm{c}}$ \\
Placental tissue Cu $(\mathrm{nmol} / \mathrm{g})$ & - & $98.1 \pm 14.7$ & $75.1 \pm 11.1^{\mathrm{d}}$ \\
Plasma Zn $(\mu \mathrm{mol} / \mathrm{l})$ & $4.03 \pm 0.58$ & $3.55 \pm 0.49^{\mathrm{a}}$ & $2.84 \pm 0.36^{\mathrm{b}, \mathrm{c}}$ \\
Placental tissue Zn $(\mathrm{nmol} / \mathrm{g})$ & - & $621 \pm 87.8$ & $490 \pm 67.1^{\mathrm{d}}$ \\
Plasma Mn $(\mathrm{nmol} / \mathrm{l})$ & $48.6 \pm 7.30$ & $42.2 \pm 7.12^{\mathrm{a}}$ & $32.2 \pm 4.73^{\mathrm{b}, \mathrm{c}}$ \\
Placental tissue Mn $(\mathrm{nmol} / \mathrm{g})$ & - & $6.75 \pm 0.81$ & $5.45 \pm 0.75^{\mathrm{d}}$ \\
\hline
\end{tabular}

${ }^{\text {a }}<0.05$, compared with plasma of NP women; ${ }^{b} \mathrm{P}<0.0001$, compared with plasma of NP women; ${ }^{\mathrm{C}} \mathrm{P}<0.001$, compared with plasma of $\mathrm{HP}$ women; ${ }^{\mathrm{d}} \mathrm{P}<0.0001$, compared with placental tissue of HP women. Se, selenium; $\mathrm{Cu}$, copper; $\mathrm{Zn}$, zinc; Mn, manganese; NP, non-pregnant; HP, healthy pregnant; RM, recurrent miscarriage.

and $\mathrm{P}<0.0001$, respectively) and $\mathrm{NP}(\mathrm{P}<0.0001)$ samples. An increase $(\mathrm{P}<0.05)$ of plasma SOA and MDA levels was observed in HP in relation to NP subjects, as well.

Levels of GPx, GSR, CAT and SOD enzymatic antioxidants. All examined plasma enzymatic antioxidants showed similar patterns of highly significant decreases in RM patients compared with both HP $(\mathrm{P}<0.001)$ and NP $(\mathrm{P}<0.0001)$ samples (Table II). However, the antioxidant plasma levels of HP participants were slightly, however significantly, decreased compared with those of NP samples $(\mathrm{P}<0.05)$. Examination of GPx, GSR, CAT and SOD in placental tissue of RM patients also revealed highly significant decreases $(\mathrm{P}<0.0001)$ compared with the levels in HP placental tissues (Table II).

\section{Non-enzymatic antioxidants}

Measurement of GSH and GSSG. GSH showed highly significant decreases in RM plasma in relation to HP $(\mathrm{P}<0.001)$ and NP $(\mathrm{P}<0.001)$ subjects (Table III). It was also observed that HP subjects had moderately lower GSH levels $(\mathrm{P}<0.05)$ compared with those in NP subjects. Similar findings were observed in placental tissue samples of RM patients which had very significantly decreased GSH levels compared with those of HP women. However, GSSG plasma levels were very significantly higher in RM patients compared with both HP $(\mathrm{P}<0.001)$ and NP $(\mathrm{P}<0.0001)$ subjects, and also in HP compared with NP subjects $(\mathrm{P}<0.05$; Table III).

GSH/GSSG ratio. As GSH is considered an important scavenger for ROS, its ratio with GSSG is used as an OS marker (23). The results (Table III) revealed that RM plasma samples had very significantly lower GSH/GSSG ratios compared with those in plasma of both HP $(\mathrm{P}<0.001)$ and NP $(\mathrm{P}<0.0001)$ subjects, and HP plasma samples had significantly lower ratio than NP $(\mathrm{P}<0.05)$ plasma. Similarly, GSH/GSSG ratios in placental tissue of RM patients were highly significantly decreased when compared with those found in HP women $(\mathrm{P}<0.0001)$.

Se, $C u, Z n$ and $M n$. The examined non-enzymatic micronutrient antioxidants (Table IV) showed very similar patterns of highly significant decreases in plasma of RM patients in relation to both HP $(\mathrm{P}<0.001)$ and NP $(\mathrm{P}<0.0001)$ subjects. 

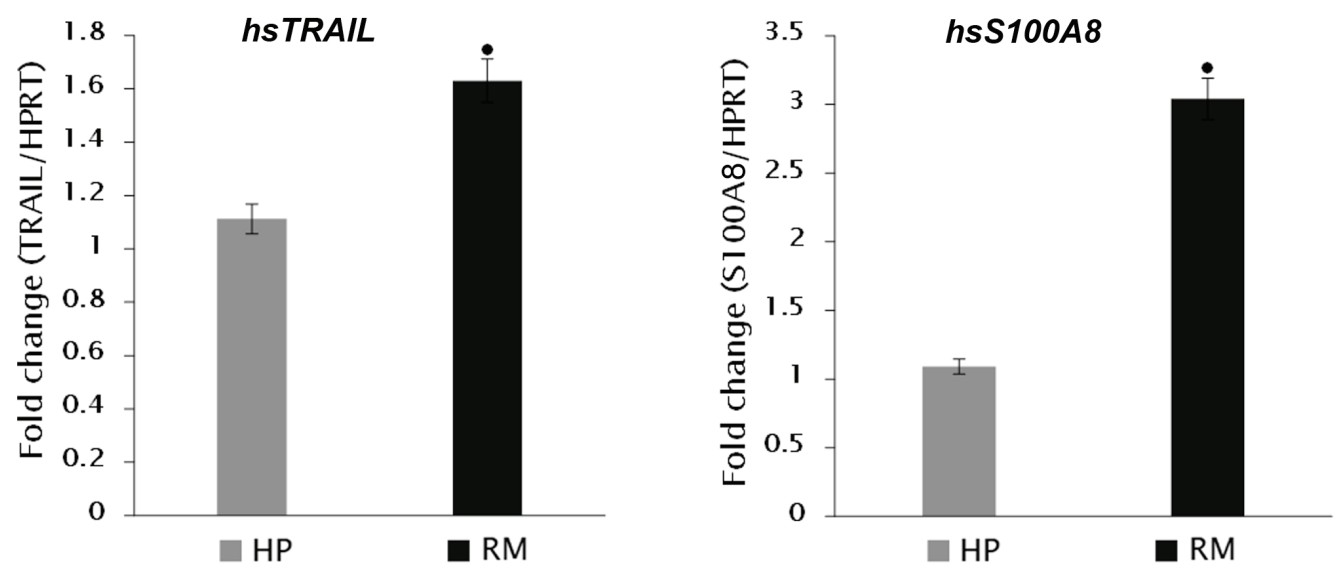

Figure 1. Relative gene expression of TRAIL and S100A8 in placental tissues of Saudi women with RM. $\bullet$ P $<0.001$. TRAIL, tumor necrosis factor-related apoptosis-inducing ligand; RM, recurrent miscarriage.
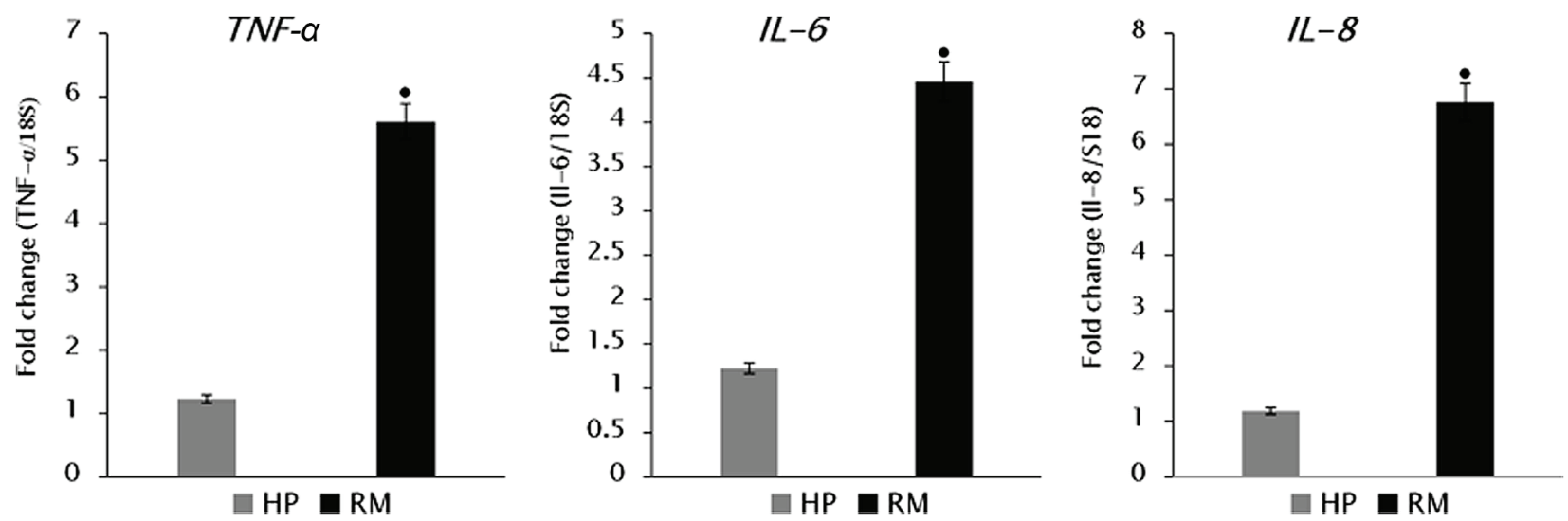

Figure 2. Relative gene expression of $T N F-\alpha, I L-6$ and $I L-8$ in placental tissues of Saudi women with RM. $\bullet P<0.001$. TNF- $\alpha$, tumor necrosis factor- $\alpha$; IL, interleukin; RM, recurrent miscarriage.
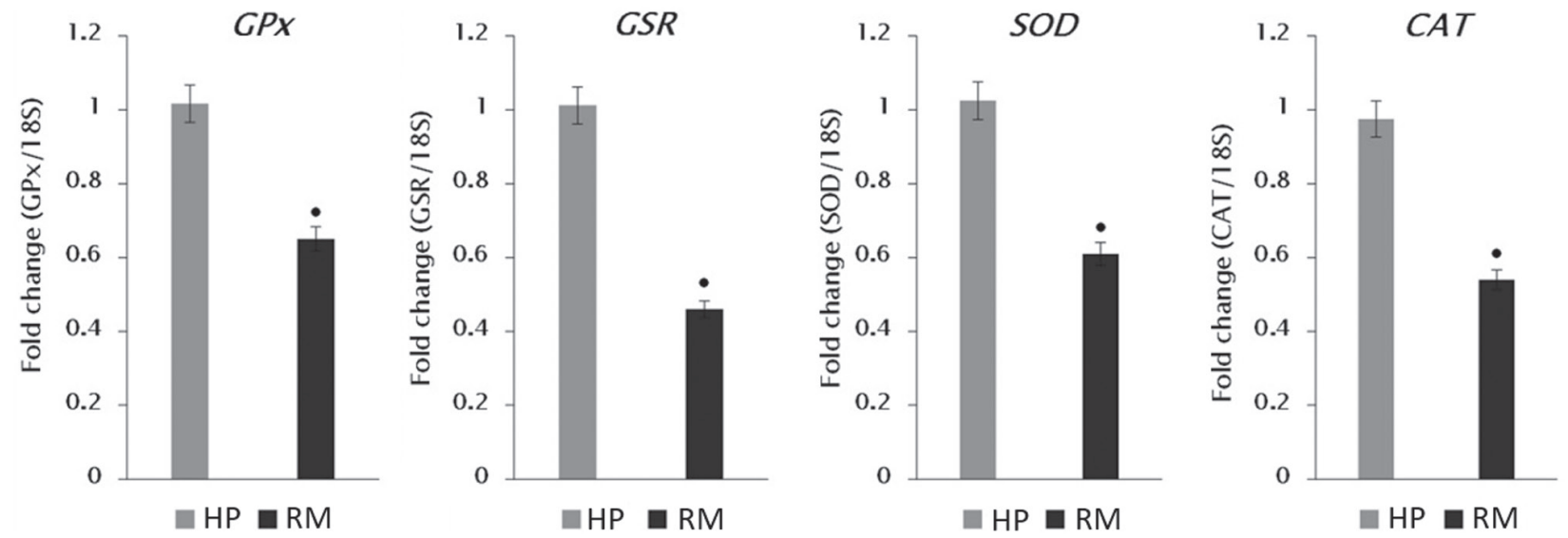

Figure 3. Relative gene expression of GPx, GSR, $S O D$ and $C A T$ in placental tissues of Saudi women with RM. ${ }^{\bullet}<0.001$. GPx, glutathione peroxidase; GSR, glutathione reductase; SOD, superoxide dismutase; CAT, catalase; RM, recurrent miscarriage.

Data also indicated that plasma micronutrient levels were moderately, however significantly, lower $(\mathrm{P}<0.05)$ in HP subjects compared with the NP ones. Furthermore, the levels of $\mathrm{Se}, \mathrm{Cu}, \mathrm{Zn}$ and $\mathrm{Mn}$ were very significantly decreased in placental samples of RM patients compared with those of HP subjects $(\mathrm{P}<0.0001)$.
Gene expression profiling

Proinflammatory TNF- $\alpha$ and cytokines as markers of OS and LPO. All pro-inflammatory cytokines and apoptosis-related genes that were selected for the expression level examination exhibited highly significant increases $(\mathrm{P}<0.001)$ in $\mathrm{RM}$ placenta samples; TRAIL (1.63 \pm 0.27 fold-change), S100A8 
(3.04 \pm 0.25 fold-change), $T N F-\alpha$ (5.61 \pm 0.26 fold-change), $I L-6$ (4.46 \pm 0.348 fold-change), and $I L-8$ (6.76 \pm 0.428 fold-change), compared with HP women (Figs. 1 and 2).

Expression of antioxidant genes. The mRNA expression levels (Fig. 3) showed highly significant decreases $(\mathrm{P}<0.001)$ of all examined antioxidant genes; $G P x$ (fold-change $0.65 \pm 0.17$ ), GSR (fold-change 0.46 \pm 0.09 ), SOD (fold-change 0.61 \pm 0.15 ), and $C A T$ (fold-change $0.55 \pm 0.087$ ), compared with the expression levels observed in the HP placental samples.

\section{Discussion}

The underlying molecular and subcellular mechanism of RM pathogenesis is not fully understood, and thus, its management is difficult and challenging (3). It was previously suggested that RM may be a result of the action of ROS generated during the first trimester of pregnancy. ROS are reactive chemical molecules involved in cell signalling and homeostasis and can be increasingly released in cell processes that involve high demand of oxygen production or consumption (24), such as placenta development. With all the evidence in the literature suggesting the association of OS in RM patients $(2,5,10)$, there is no consensus regarding its negative impact and the underlying mechanism. Therefore, in addition to measuring levels of some OS markers, the current study examined the levels of a comprehensive list of key antioxidants in plasma and placental tissue of RM patients in relation to those of HP and NP participants in order to test the effect of OS. Moreover, the molecular basis of RM remains unclear, thus the present study also attempted to quantify the gene expression of some antioxidant enzymes and selected pro-inflammatory and apoptosis-related genes in placental tissue of RM patients compared with those of HP subjects.

LPO, resulting from ROS, can cause disruption in the membrane lipid bilayer that may inactivate membrane-bound receptors and enzymes, increasing the tissue permeability (25). Current results showed highly significantly increased LPO levels in plasma and placental tissues of RM patients compared with those of HP and NP women. High LPO, as gestation progresses, has been previously reported in placenta and umbilical cord (17). Similar results have also been obtained by others reporting elevated MDA in the serum of RM women and increase has also been observed in the villous decidual tissues of women with early pregnancy loss (26). This has also been supported by other studies that showed increase of MDA levels in serum of failed pregnancy (27) and in RM women (28). The consensus between current findings and previous studies supports the suggestion that increased plasma and placental LPO is a high risk factor causing oxidative cell damage that might result in miscarriage. SOA are the most common oxygen-free radicals created from molecular oxygen by an electron addition. SOA cannot penetrate the lipid membrane and is mostly present within its production compartment (29). The present study demonstrated that the levels of SOA and $\mathrm{H}_{2} \mathrm{O}_{2}$ generation rates in plasma and placental tissue of RM patients are highly significantly increased compared with those of HP and NP women, and are moderately increased in plasma of HP women compared with those of NP women. SOA generation within and out of the cell is an initial step in ROS formation. Therefore, increased levels in plasma or placental tissue will result in OS, and may have a direct effect on causing RM. Dismutation of SOA and production of $\mathrm{H}_{2} \mathrm{O}_{2}$ are catalysed by $\mathrm{SOD}$, which is regarded as the first line of defence. $\mathrm{H}_{2} \mathrm{O}_{2}$ is not a free radical, however due to its high ability to penetrate biological membranes is considered important by being an intermediate molecule in forming more ROS radicals, such as hydroxyl, which can cause increased damage to biological systems, more than any other radical (30).

During normal pregnancy, the placental OS is balanced by the quenching of ROS through the action of antioxidant enzymes, including SOD, CAT, GPx and GSR, that act together with non-enzymatic antioxidants, such as vitamin $\mathrm{C}$ and E, Se, and GSH. This antioxidant control system of OS in normal pregnancy is suggested to be a causative factor of RM when insufficiently functioning. Thus, relating RM to OS may not only be due to increased ROS generation in early gestation, but can also result from insufficient levels of antioxidants required to combat the excessive ROS, both of which have been demonstrated in RM subjects of this study. It is likely that the significantly low GPx activity and downregulation of its gene transcripts that was documented in the plasma and placental tissue of RM patients in current study, was due to the decreased levels of glutathione required for the elimination of excessive ROS in RM women. Similar results have been previously obtained showing that serum GPx activities are significantly decreased in RM patients compared with NP women $(26,28)$, and in HP women compared with NP women (30). Similarly, SOD activity levels in the current study showed significant decreases in both plasma and placental tissue of RM patients compared with those of HP women. Moreover, the mRNA expression levels of SOD were found to be significantly downregulated in trophoblast cells isolated from RM placentas. This conforms with previous studies that have reported similar significantly low levels of SOD in RM patients compared with HP women $(28,31,32)$. This suggests that decreased levels of SOD enzyme in placental tissue might be associated with increased generation of SOA, and thus of OS, that may be involved in the pathogenesis of RM.

The control of $\mathrm{H}_{2} \mathrm{O}_{2}$ production is the second enzymatic step that plays a vital role against ROS propagation, and CAT and GPx catalyse the conversion of $\mathrm{H}_{2} \mathrm{O}_{2}$ to $\mathrm{H}_{2} \mathrm{O}$. Indeed, GPx is the only enzyme able to quench $\mathrm{H}_{2} \mathrm{O}_{2}$ in mitochondria, since CAT is not expressed there, and requires GSH to convert $\mathrm{H}_{2} \mathrm{O}_{2}$ into $\mathrm{H}_{2} \mathrm{O}$. In the present study, CAT activity and its gene transcripts underwent highly significant decreases and downregulation in plasma and placental tissue of RM patients compared with those of HP and NP women. Other studies have also reported significant decreases in serum CAT activity in RM patients compared with HP women $(28,32)$. Thus, it is hypothesized that the decreases in CAT activity were due to its consumption in protecting cells from the harmful effect of $\mathrm{H}_{2} \mathrm{O}_{2}$. The present study also profiled differential mRNA expression levels of GPX, GSR, SOD and CAT genes, in placental tissue of RM patients compared with those of HP women. The observed downregulation in the expression of all investigated antioxidant enzyme levels might be linked to the detrimental impact of OS on trophoblast cells, whereby leading to ROS generation that may inactivate both de novo protein synthesis, as well as gene transcription processes. 
GSR and NADPH are important to maintain glutathione in its active reduced state via the redox cycle activity. Under the high OS conditions observed in the present study, GSH levels were lowered, and subsequently the GSSG content was significantly higher leading to a very significant drop in the GSH/GSSG ratio in RM patients compared with HP and NP women. The GSH/GSSG ratio represents the major cellular redox buffer, and therefore is a representative indicator of the redox environment of the cell (33). This observed reduction in GSH/GSSG ratio should have been met with a proportional increase in GSR activity in order to reduce the GSSG back to $\mathrm{GSH}$, thereby maintaining the natural balance of those two parameters. However, the present results indicated significantly low GSR activity in plasma and placental tissue of RM patients compared with those of HP women, which is in agreement with previous studies $(28,32,34)$. This decrease in the enzyme activity might be a direct consequence of OS damage caused by increased GSSG levels, leading to downregulation of GSR gene expression levels presently noted.

Pregnancy comes with physiological changes that can cause reduced bioavailability of some dietary components in addition to the increased demand for various nutrients and micronutrients for developing the foetus (35). Se is known to be significantly low during pregnancy and decreased levels in the blood of HP women have been reported during delivery compared with those of NP women $(33,36)$, pre-eclamptic patients (37), as well as recurrent loss and pre-term delivery patients (38) relative to HP women. Results of the current study indicated a very significant reduction in the plasma and placental tissue of RM patients compared with HP subjects. Changes in Se homeostasis during pregnancy are probably caused by increased oxygen demand in the mother's body and developing foetus. A potential reason behind the increased demand for Se during pregnancy may be the increased mass of erythrocytes in the foetus (38). It has been suggested that the loss of antioxidant capacity might be attributed to low Se, leading to damage to biological membranes and DNA (39), which may cause $\mathrm{RM} . \mathrm{Cu}, \mathrm{Zn}$ and $\mathrm{Mn}$ are important cofactors for a number of antioxidant enzymes, including $\mathrm{Cu} / \mathrm{Zn}-\mathrm{SOD}$ and $\mathrm{Mn}$-SOD that may protect the placenta from generating SOA and initiation of OS. In the present study, the levels of $\mathrm{Cu}, \mathrm{Zn}$ and $\mathrm{Mn}$ in plasma and placental tissues of RM patients were significantly lower compared with those of HP women. This is in agreement with previous studies that have reported significant decreases in $\mathrm{Cu}$ and $\mathrm{Zn}$ levels in serum of women with unexplained RM compared with normal HP women (26). Results of the present study also indicated significantly decreased plasma $\mathrm{Cu}, \mathrm{Zn}$ and $\mathrm{Mn}$ in HP subjects compared with NP women. To this end, several studies have reported that, whereas plasma $\mathrm{Zn}$ concentrations decline as the pregnancy progresses $(16,40,41), \mathrm{Cu}$ plasma levels increase before returning to normal NP values after delivery $(40,41)$. The increased levels with the progression of pregnancy could be partly related to synthesis of ceruloplasmin, a major $\mathrm{Cu}$-binding protein, due to altered levels of oestrogen (41).

This study also profiled the mRNA expression levels of pro-inflammatory cytokines (TNF- $\alpha, I L-6$ and $I L-8), S 100 A 8$ and TRAIL in RM samples compared with HP women. TRAIL is also a TNF member that can induce apoptosis via its apoptotic receptors (42). Apoptosis plays an important role in normal human placental development and any altered balance between proliferation and apoptosis of villous trophoblast is associated with abnormal pregnancies (43). Increased levels of villous trophoblast apoptosis have been identified in several placental pathologies including RM (44). TRAIL and its receptors appear to be differentially expressed in villous placenta. Expression of TRAIL and its two decoy receptors DcR1 and DcR2 are localized predominantly in the syncytiotrophoblast, whereas cytotrophoblast cells have been shown to express high levels of DR4 and DR5 (45) that trigger apoptotic signalling via activation of the classic caspase-dependent 'death' pathway (46). It has been previously shown (47) that TRAIL and S100A8 are differentially expressed genes in placental tissue in RM compared with normal pregnancy. The study also suggested that TRAIL can be used as a potential predictive biomarker in maternal serum for early pregnancy complications (47). This supports our current findings of highly significant expression levels of both TRAIL and S100A8 in placental tissue of RM compared with HP samples. Similar findings have been previously documented (48) demonstrating that serum TRAIL is significantly increased in patients of RM. This suggests that TRAIL might have a direct effect on RM and could be used as a predictive biomarker in maternal serum in women with history of RM.

A number of cytokines have been reported essential for the reproductive processes, and it has been suggested that a lower index of T-helper1/T-helper2 (Th1/Th2) immune response supports a physiological pregnancy (49). The increased production of Th1 cytokines, such as TNF- $\alpha$ and interferon- $\gamma$ (IFN- $\gamma)$, compared with the Th2 cytokine has been linked to recurrent spontaneous abortions (50). TNF- $\alpha$ is a cytokine that is important in inflammation and has been strongly suggested to have a role in cardiovascular disease pathogenesis. TNF- $\alpha$ is also found during most inflammatory stages and can trigger the production of the pro-inflammatory cytokine IL-6 (51). Proinflammatory cytokines have been suggested as markers for OS and LPO (52).

It has been demonstrated that TNF- $\alpha$ acts in synergism with other inflammatory cytokines and stimulates the synthesis and release of prostaglandins inducing uterine contractions and the onset of labour (53). It has also been proposed that TNF- $\alpha$ plays an important role in apoptosis. Cytokine receptors, such as tumor necrosis factor-receptor 1 (TNF-R1), have also been associated with miscarriage. This is probably due to their role as apoptotic mediators through pro-inflammatory cytokines, such as TNF- $\alpha$ (54). TNF- $\alpha$ can inhibit the proliferation of human trophoblast cells in vitro (55) and the administration of TNF- $\alpha$ and INF- $\gamma$ to normal pregnant mice has been shown to lead to abortion (55). Our findings indicated significant increases in the expression levels of $T N F-\alpha$ in placental tissue of RM patients compared with those of HP women. These results are supported by previous findings of the expression of $T N F-\alpha$ in peripheral blood cells (56) and the similar high significant increase in serum $T N F-\alpha$ in RM compared with HP women $(28,32)$. Taken together, these findings suggest that OS and TNF- $\alpha$ have a potential detrimental effect on pregnancy and high levels may play an important role in the pathogenesis of RM.

Cytokines are also known to play an important role in implantation and balance of locally produced pro-inflammatory, and 
anti-inflammatory cytokines have been previously suggested to be critical for a successful pregnancy (57). Thus, imbalanced cytokine production may occur in early pregnancy loss. TNF- $\alpha$ and IL-6, as inflammatory factors, may have immune-modulatory and anti-inflammatory effects in addition to maintaining the maternal-foetal immune tolerance. Their overexpression could induce several pathologies including RM (58-61). The current results demonstrated that the expression levels of $T N F-\alpha$ and $I L-6$ in placental tissues of RM patients were significantly higher than those of HP women. To this end, it has been reported that any disturbance in the balance of TNF- $\alpha$ and $I L-6$ could eventually lead to miscarriage $(62,63)$. It has been previously shown that TNF- $\alpha$ and IL- 6 concentrations in murine trophoblasts with recurrent spontaneous abortion are significantly higher than in control group (63). This suggests that TNF- $\alpha$ and IL- 6 might play an important role in the embryonic development as well. IL-8 is a pro-inflammatory cytokine that is often associated with inflammation and its secretion is increased by OS, thereby causing recruitment of inflammatory cells and inducing further increase in OS mediators (64). The present results showed upregulated mRNA expression of $I L-8$ gene in the placental tissue of RM women compared with HP samples. It is thus proposed that the increased mRNA expression levels of pro-inflammatory cytokines in placental tissue could be considered as another causative factor of the pathogenesis of RM.

In conclusion, the current results confirm several previous studies linking OS and RM. Antioxidant and pro-oxidant status might be a useful tool in estimating the risk of OS and associated diseases and they are becoming increasingly important. This is because they may assist in designing strategies for the prevention and management of OS. Such strategies include the use of micronutrient supplements to maintain effective antioxidant defence in women at risk of RM.

\section{Acknowledgements}

Not applicable.

\section{Funding}

This project was financially supported by King Saud University, Vice Deanship of Research Chairs.

\section{Availability of data and materials}

The datasets used and/or analyzed during the current study are available from the corresponding author on reasonable request.

\section{Authors' contributions}

MAMAS, YAAS and AFA conceived and designed the study. MAMAS, MMA and AFA were responsible for the methodology. MAMAS, FSA, HKG and YAAS were responsible for the data validation. YAAS, HKG and MAMAS performed formal analysis. MAMAS, YAAS, MMA and HKG were involved in the investigative aspects of the study. YAAS and MMA provided resources. MAMAS and FSA wrote and prepared the original draft. MAMAS wrote, reviewed and edited the manuscript. YAAS was responsible for the project administration and funding acquisition. All authors read and approved the final manuscript.

\section{Ethics approval and consent to participate}

Ethics approval was obtained from the Ethics Review Committee of the College of Applied Medical Sciences of King Saud University (CAMS 27-34/35; Riyadh, Kingdom of Saudi Arabia). Signed consent forms were obtained from all subjects who participated in this research.

\section{Patient consent for publication}

Not applicable.

\section{Competing interests}

The authors declare that they have no competing interests.

\section{References}

1. Goodale LF, Hayrabedyan S, Todorova K, Roussev R, Ramu S, Stamatkin C, Coulam CB, Barnea ER and Gilbert RO: Pre implantation factor (PIF) protects cultured embryos against oxidative stress: Relevance for recurrent pregnancy loss (RPL) therapy. Oncotarget 8: 32419-32432, 2017.

2. Fortis MF, Fraga LR, Boquett JA, Kowalski TW, Dutra CG, Gonçalves RO, Vianna FSL, Schüler-Faccini L and Sanseverino MT: Angiogenesis and oxidative stress-related gene variants in recurrent pregnancy loss. Reprod Fertil Dev 30: 498-506, 2018.

3. Tur-Torres MH, Garrido-Gimenez C and Alijotas-Reig J: Genetics of recurrent miscarriage and fetal loss. Best Pract Res Clin Obstet Gynaecol 42: 11-25, 2017.

4. Azani A, Hosseinzadeh A, Azadkhah R, Zonouzi AA, Zonouzi AP, Aftabi Y, Khani H, Heidary L, Danaii S, Bargahi N, et al: Association of endothelial nitric oxide synthase gene variants $(-786 \mathrm{~T}>\mathrm{C}$, intron $4 \mathrm{~b} / \mathrm{a}$ VNTR and $894 \mathrm{G}>\mathrm{T})$ with idiopathic recurrent pregnancy loss: A case-control study with haplotype and in silico analysis. Eur J Obstet Gynecol Reprod Biol 215: 93-100, 2017.

5. Gupta S, Agarwal A, Banerjee J and Alvarez JG: The role of oxidative stress in spontaneous abortion and recurrent pregnancy loss: A systematic review. Obstet Gynecol Surv 62: 335-347, quiz 353-354, 2007.

6. Ghneim HK, Al-Sheikh YA, Alshebly MM and Aboul-Soud MA: Superoxide dismutase activity and gene expression levels in Saudi women with recurrent miscarriage. Mol Med Rep 13: 2606-2612, 2016.

7. Ghneim HK and Alshebly MM: Biochemical markers of oxidative stress in Saudi women with recurrent miscarriage. J Korean Med Sci 31: 98-105, 2016.

8. Yiyenoğlu ÖB, Uğur MG, Özcan HÇ, Can G, Öztürk E, Balat Ö and Erel Ö: Assessment of oxidative stress markers in recurrent pregnancy loss: A prospective study. Arch Gynecol Obstet 289: 1337-1340, 2014.

9. Pereira AC and Martel F: Oxidative stress in pregnancy and fertility pathologies. Cell Biol Toxicol 30: 301-312, 2014.

10. Park S, Lim W, Bazer FW and Song G: Naringenin suppresses growth of human placental choriocarcinoma via reactive oxygen species-mediated P38 and JNK MAPK pathways. Phytomedicine 50: 238-246, 2018.

11. Menezo YJ, Silvestris E, Dale B and Elder K: Oxidative stress and alterations in DNA methylation: Two sides of the same coin in reproduction. Reprod Biomed Online 33: 668-683, 2016.

12. Ishii T, Yasuda K, Miyazawa M, Mitsushita J, Johnson TE, Hartman PS and Ishii N: Infertility and recurrent miscarriage with complex II deficiency-dependent mitochondrial oxidative stress in animal models. Mech Ageing Dev 155: 22-35, 2016.

13. Dröse S and Brandt U: Molecular mechanisms of superoxide production by the mitochondrial respiratory chain. In: Mitochondrial Oxidative Phosphorylation. Springer, Berlin, pp145-169, 2012. 
14. Couto N, Malys N, Gaskell SJ and Barber J: Partition and turnover of glutathione reductase from Saccharomyces cerevisiae: A proteomic approach. J Proteome Res 12: 2885-2894, 2013.

15. Johnston RB Jr, Keele BB Jr, Misra HP, Lehmeyer JE, Webb LS, Baehner RL and RaJagopalan KV: The role of superoxide anion generation in phagocytic bactericidal activity. Studies with normal and chronic granulomatous disease leukocytes. J Clin Invest 55: 1357-1372, 1975

16. Ilhan N, Ilhan N and Simsek M: The changes of trace elements, malondialdehyde levels and superoxide dismutase activities in pregnancy with or without preeclampsia. Clin Biochem 35 393-397, 2002.

17. Saleh S, Maraqa AD and Ali ME: Regional distribution of superoxide dismutase activity in human placenta and its correlation with lipid peroxidation. Jordan J Biol Sci 3: 125-132, 2010

18. Aebi H: Catalase in vitro. Methods Enzymol 105: 121-126, 1984.

19. Ghneim HK and Al-Sheikh YA: Effect of selenium supplementation on glutathione peroxidase and catalase activities in senescent cultured human fibroblasts. Ann Nutr Metab 59: $127-138,2011$.

20. Gherghel D, Griffiths HR, Hilton EJ, Cunliffe IA and Hosking SL: Systemic reduction in glutathione levels occurs in patients with primary open-angle glaucoma. Invest Ophthalmol Vis Sci 46: 877-883, 2005

21. Gherghel D, Mroczkowska S and Qin L: Reduction in blood glutathione levels occurs similarly in patients with primary-open angle or normal tension glaucoma. Invest Ophthalmol Vis Sci 54 3333-3339, 2013.

22. Osada H, Watanabe Y, Nishimura Y, Yukawa M, Seki K and Sekiya S: Profile of trace element concentrations in the feto-placental unit in relation to fetal growth. Acta Obstet Gynecol Scand 81: 931-937, 2002.

23. Zitka O, Skalickova S, Gumulec J, Masarik M, Adam V, Hubalek J, Trnkova L, Kruseova J, Eckschlager T and Kizek R: Redox status expressed as GSH:GSSG ratio as a marker for oxidative stress in paediatric tumour patients. Oncol Lett 4: 1247-1253, 2012

24. Kim J, Yun M, Kim EO, Jung DB, Won G, Kim B, Jung JH and Kim SH: Decursin enhances TRAIL-induced apoptosis through oxidative stress mediated-endoplasmic reticulum stress signalling in non-small cell lung cancers. Br J Pharmacol 173: 1033-1044, 2016

25. Girotti AW: Mechanisms of lipid peroxidation. J Free Radic Biol Med 1: 87-95, 1985

26. Talat T: The relationship between serum copper, zinc, and glutathione peroxidase with malondialdehyde in women with unexplained recurrent miscarriage. Kufa Med J 12: 29-37, 2009.

27. Sugino N, Nakata M, Kashida S, Karube A, Takiguchi S and Kato H: Decreased superoxide dismutase expression and increased concentrations of lipid peroxide and prostaglandin $\mathrm{F}(2 \alpha)$ in the decidua of failed pregnancy. Mol Hum Reprod 6 : 642-647, 2000

28. El-Far M, El-Sayed IH, El-Motwally A-G, Hashem IA and Bakry N: Tumor necrosis factor- $\alpha$ and oxidant status are essential participating factors in unexplained recurrent spontaneous abortions. Clin Chem Lab Med 45: 879-883, 2007.

29. Aledo JC: Life-history constraints on the mechanisms that control the rate of ROS production. Curr Genomics 15: 217-230, 2014.

30. Betteridge DJ: What is oxidative stress? Metabolism 49 (Suppl 1): 3-8, 2000.

31. Jenkins C, Wilson R, Roberts J, Miller H, McKillop JH and Walker JJ: Antioxidants: Their role in pregnancy and miscarriage. Antioxid Redox Signal 2: 623-628, 2000.

32. El-Far M, El-Sayed IH, El-Motwally AE, Hashem IA and Bakry N: Serum levels of TNF- $\alpha$ and antioxidant enzymes and placental TNF- $\alpha$ expression in unexplained recurrent spontaneous miscarriage. J Physiol Biochem 65: 175-181, 2009.

33. Schafer FQ and Buettner GR: Redox environment of the cell as viewed through the redox state of the glutathione disulfide/glutathione couple. Free Radic Biol Med 30: 1191-1212, 2001.

34. Vural P, Akgül C, Yildirim A and Canbaz M: Antioxidant defence in recurrent abortion. Clin Chim Acta 295: 169-177, 2000.

35. Maggini S, Wintergerst ES, Beveridge S and Hornig DH: Selected vitamins and trace elements support immune function by strengthening epithelial barriers and cellular and humoral immune responses. Br J Nutr 98 (Suppl 1): S29-S35, 2007.

36. Zachara BA, Dobrzyński W, Trafikowska U and Szymański W: Blood selenium and glutathione peroxidases in miscarriage. BJOG 108: 244-247,2001.
37. Haque MM, Moghal MMR, Sarwar MS, Anonna SN, Akter M, Karmakar P, Ahmed S, Sattar MA and Islam MS: Low serum selenium concentration is associated with preeclampsia in pregnant women from Bangladesh. J Trace Elem Med Biol 33: $21-25,2016$

38. Rayman MP, Wijnen H, Vader H, Kooistra L and Pop V: Maternal selenium status during early gestation and risk for preterm birth CMAJ 183: 549-555, 2011.

39. Barrington JW, Taylor M, Smith S and Bowen-Simpkins P: Selenium and recurrent miscarriage. J Obstet Gynaecol 17: 199-200, 1997.

40. Izquierdo Alvarez S, Castañón SG, Ruata MLC, Aragüiés EF, Terraz PB, Irazabal YG, González EG and Rodríguez BG: Updating of normal levels of copper, zinc and selenium in serum of pregnant women. J Trace Elem Med Biol 21 (Suppl 1): 49-52, 2007.

41. Liu J, Yang H, Shi H, Shen C, Zhou W, Dai Q and Jiang Y: Blood copper, zinc, calcium, and magnesium levels during different duration of pregnancy in Chinese. Biol Trace Elem Res 135: $31-37,2010$

42. Wang S and El-Deiry WS: TRAIL and apoptosis induction by TNF-family death receptors. Oncogene 22: 8628-8633, 2003

43. Sharp AN, Heazell AE, Crocker IP and Mor G: Placental apoptosis in health and disease. Am J Reprod Immunol 64: 159-169, 2010.

44. Choi HK, Choi BC, Lee SH, Kim JW, Cha KY and Baek KH: Expression of angiogenesis- and apoptosis-related genes in chorionic villi derived from recurrent pregnancy loss patients. Mol Reprod Dev 66: 24-31, 2003.

45. Chen L, Liu X, Zhu Y, Cao Y, Sun L and Jin B: Localization and variation of TRAIL and its receptors in human placenta during gestation. Life Sci 74: 1479-1486, 2004.

46. Walczak $\mathrm{H}$ and Haas TL: Biochemical analysis of the native trail death-inducing signaling complex. Methods Mol Biol 414: 221-239, 2008.

47. Rull K, Tomberg K, Kõks S, Männik J, Möls M, Sirotkina M, Värv S and Laan M: Increased placental expression and maternal serum levels of apoptosis-inducing TRAIL in recurrent miscarriage. Placenta 34: 141-148, 2013

48. Agostinis C, Bulla R, Tisato V, De Seta F, Alberico S, Secchiero P and Zauli G: Soluble TRAIL is elevated in recurrent miscarriage and inhibits the in vitro adhesion and migration of HTR8 trophoblastic cells. Hum Reprod 27: 2941-2947, 2012.

49. Raghupathy R, Makhseed M, Azizieh F, Omu A, Gupta M and Farhat R: Cytokine production by maternal lymphocytes during normal human pregnancy and in unexplained recurrent spontaneous abortion. Hum Reprod 15: 713-718, 2000.

50. Reid JG, Simpson NA, Walker RG, Economidou O, Shillito J, Gooi HC, Duffy SR and Walker JJ: The carriage of pro-inflammatory cytokine gene polymorphisms in recurrent pregnancy loss. Am J Reprod Immunol 45: 35-40, 2001.

51. Pearson D and Shaw S: Proinflammatory cytokine tumor necrosis factor-alpha increases with hostility and aggression. Life Enhancement Mag 7: 2004. http://206.220.200.3/magazine/ article/1002-proinflammatory-cytokine-tumor-necrosis-factoralpha.

52. Stentz FB, Umpierrez GE, Cuervo $\mathrm{R}$ and Kitabchi AE: Proinflammatory cytokines, markers of cardiovascular risks, oxidative stress, and lipid peroxidation in patients with hyperglycemic crises. Diabetes 53: 2079-2086, 2004.

53. Haddad EK, Duclos AJ and Baines MG: Early embryo loss is associated with local production of nitric oxide by decidual mononuclear cells. J Exp Med 182: 1143-1151, 1995.

54. Yu XW, Yan CF, Jin H and Li X: Tumor necrosis factor receptor 1 expression and early spontaneous abortion. Int J Gynaecol Obstet 88: 44-48, 2005.

55. Chaouat G, Menu E, Clark DA, Dy M, Minkowski $M$ and Wegmann TG: Control of fetal survival in CBA x DBA/2 mice by lymphokine therapy. J Reprod Fertil 89: 447-458, 1990.

56. Daher S, Fonseca F, Ribeiro OG, Musatti CC and GerbaseDeLima M: Tumor necrosis factor during pregnancy and at the onset of labor and spontaneous abortion. Eur J Obstet Gynecol Reprod Biol 83: 77-79, 1999.

57. Choi YK and Kwak-Kim J: Cytokine gene polymorphisms in recurrent spontaneous abortions: A comprehensive review. Am J Reprod Immunol 60: 91-110, 2008.

58. Lin QD and Qiu LH: Pathogenesis, diagnosis, and treatment of recurrent spontaneous abortion with immune type. Front Med China 4: 275-279, 2010 . 
59. Teklenburg G, Salker M, Heijnen C, Macklon NS and Brosens JJ: The molecular basis of recurrent pregnancy loss: Impaired natural embryo selection. Mol Hum Reprod 16: 886-895, 2010.

60. Li D and Li J: Association of miR-34a-3p/5p, miR-141-3p/5p, and miR-24 in decidual natural killer cells with unexplained recurrent spontaneous abortion. Med Sci Monit 22: 922-929, 2016.

61. Finan RR, Al-Irhayim Z, Mustafa FE, Al-Zaman I, MohammedFA, Al-Khateeb GM, Madan S, Issa AA and Almawi WY: Tumor necrosis factor- $\alpha$ polymorphisms in women with idiopathic recurrent miscarriage. J Reprod Immunol 84: 186-192, 2010.

62. Xiao SJ, Zhao AM and Bao SM: Relationship between expression of cox-2, its signal transduction pathways and autoimmune-type recurrent miscarriage. J Shanghai Jiaotong Univ (Medical Science) 7: 007, 2011.
63. Hua F, Li CH, Wang $\mathrm{H}$ and Xu HG: Relationship between expression of COX-2, TNF- $\alpha$, IL- 6 and autoimmune-type recurrent miscarriage. Asian Pac J Trop Med 6: 990-994, 2013.

64. Vlahopoulos S, Boldogh I, Casola A and Brasier AR: Nuclear factor-kappaB-dependent induction of interleukin-8 gene expression by tumor necrosis factor $\alpha$ : Evidence for an antioxidant sensitive activating pathway distinct from nuclear translocation. Blood 94: 1878-1889, 1999.

cc) (i) () Attribution-NonCommercial-NoDerivatives 4.0 International (CC BY-NC-ND 4.0) License. 